University of Nebraska - Lincoln

DigitalCommons@University of Nebraska - Lincoln

Response of palila and other subalpine Hawaiian forest bird species to prolonged drought and habitat degradation by feral ungulates

\author{
Paul C. Banko \\ U.S. Geological Survey, paul_banko@usgs.gov \\ Richard J. Camp \\ U.S. Geological Survey, rick_camp@usgs.gov \\ Chris Farmer \\ American Bird Conservancy, cfarmer@abcbirds.org \\ Kevin W. Brinck \\ U.S. Geological Survey, kevin_brink@usgs.gov \\ David L. Leonard \\ University of Hawaii at Manoa, David.L.Leonard@Hawaii.gov \\ See next page for additional authors
}

Follow this and additional works at: https://digitalcommons.unl.edu/usgsstaffpub

Banko, Paul C.; Camp, Richard J.; Farmer, Chris; Brinck, Kevin W.; Leonard, David L.; and Stephens, Robert M., "Response of palila and other subalpine Hawaiian forest bird species to prolonged drought and habitat degradation by feral ungulates" (2013). USGS Staff -- Published Research. 636.

https://digitalcommons.unl.edu/usgsstaffpub/636

This Article is brought to you for free and open access by the US Geological Survey at DigitalCommons@University of Nebraska - Lincoln. It has been accepted for inclusion in USGS Staff -- Published Research by an authorized administrator of DigitalCommons@University of Nebraska - Lincoln. 


\section{Authors}

Paul C. Banko, Richard J. Camp, Chris Farmer, Kevin W. Brinck, David L. Leonard, and Robert M. Stephens 


\title{
Response of palila and other subalpine Hawaiian forest bird species to prolonged drought and habitat degradation by feral ungulates
}

\author{
Paul C. Banko ${ }^{\mathrm{a}, *}$, Richard J. Camp ${ }^{\mathrm{b}}$, Chris Farmer ${ }^{\mathrm{b}, \mathrm{c}}$, Kevin W. Brinck ${ }^{\mathrm{b}}$, David L. Leonard ${ }^{\mathrm{d}}$, \\ Robert M. Stephens ${ }^{\mathrm{e}}$ \\ ${ }^{a}$ U.S. Geological Survey, Pacific Island Ecosystems Research Center, PO Box 44, Hawai'i National Park, HI 96718, United States \\ ${ }^{\text {b } H a w a i ' i ~ C o o p e r a t i v e ~ S t u d i e s ~ U n i t, ~ U n i v e r s i t y ~ o f ~ H a w a i ' i ~ a t ~ H i l o, ~ P O ~ B o x ~ 44, ~ H a w a i ' i ~ N a t i o n a l ~ P a r k, ~ H I ~ 96718, ~ U n i t e d ~ S t a t e s ~}$ \\ ${ }^{\mathrm{c}}$ American Bird Conservancy, PO Box 44, Hawai'i National Park, HI 96718, United States \\ ${ }^{\mathrm{d}}$ Pacific Cooperative Studies Unit, University of Hawai'i at Mānoa, 1151 Punchbowl St., Honolulu, HI 96813, United States \\ e Pacific Cooperative Studies Unit, University of Hawai'i at Mānoa, 19 East Kawili St., Hilo, HI 96720, United States
}

\section{A R T I C L E I N F O}

\section{Article history:}

Received 14 March 2012

Received in revised form 6 June 2012

Accepted 12 July 2012

\section{Keywords:}

Drought

Endangered species

Hawai'i

Palila

Population trends

Specialist

Ungulate impacts

\begin{abstract}
A B S T R A C T
Extinction has claimed half of all historically-known Hawaiian passerines, and today many extant species are increasingly threatened due to the combined effects of invasive species and climate change. Habitat disturbance has affected populations of feeding specialists most profoundly, and our results indicate that specialists continue to be most vulnerable, although even some abundant, introduced, generalist species also may be affected. Surveys of passerines during 1998-2011 in subalpine woodland habitat on Mauna Kea Volcano, Island of Hawai'i, revealed that the abundance of the critically endangered palila (Loxioides bailleui), a seed specialist, declined by $79 \%$ after 2003. The 'akiapōlā'au (Hemignathus munroi), an endangered specialist insectivore, was not detected in the survey area after 1998. The Hawai'i 'amakihi (Hemignathus virens virens), a generalist feeder and the most abundant species on Mauna Kea, was the only native species to maintain a stable population. The Japanese white-eye (Zosterops japonicus), a wellentrenched generalist and one of the three most common introduced species, declined. Drought prevailed in $74 \%$ of months during $2000-2011$, and dry conditions contributed to the recent decline of the palila by reducing the annual māmane (Sophora chrysophylla) seed pod crop, which influences palila breeding and survival. Sustained browsing by introduced ungulates also lowered habitat carrying capacity, and their elimination should reduce the effects of drought and promote forest restoration. Our results illustrate how the feeding ecology of a species can influence its response to interacting environmental perturbations, and they underscore the value of long-term monitoring to detect population trends of sensitive species.
\end{abstract}

Published by Elsevier Ltd.

\section{Introduction}

The decline of specialist species contributes substantially to the overall loss of global biodiversity (Clavel et al., 2011). Most globally threatened birds are tropical forest-dwelling species, but birds endemic to islands are most vulnerable to extinction (Birdlife International, 2000). Since 1800 , more than $90 \%$ of bird extinctions have occurred on islands, and in the Hawaiian Islands 14 of 44 species of historically-known forest passerines (songbirds) are extinct while 20 are listed as endangered, although 9 of these, most of

\footnotetext{
* Corresponding author. Tel.: +1 808985 6402; fax: +1 8089678568 .

E-mail addresses: paul_banko@usgs.gov (P.C. Banko), rick_camp@usgs.gov (R.J. Camp), cfarmer@abcbirds.org (C. Farmer), kevin_brink@usgs.gov (K.W. Brinck), David.L.Leonard@Hawaii.gov (D.L. Leonard), robertms@hawaii.edu (R.M. Stephens).
}

which are Hawaiian honeycreepers (Fringillidae: Drepanidinae), have not been seen in decades (Banko and Banko, 2009). The feeding specialists, species with unusual bills and relatively constrained or stereotypic feeding behaviors, have all disappeared or are in danger of extinction, whereas about one-third (10 species) of non-specialized passerines are still not considered threatened (Banko and Banko, 2009).

The palila (Loxioides bailleui), a species of Hawaiian honeycreeper, is ranked among the 150 most critically endangered bird species (Birdlife International, 2011), and its population and range are declining rapidly. The palila is the last honeycreeper species restricted to dry forest habitat, and it depends on the unhardened seeds that it extracts from the green pods of the māmane (Sophora chyrsophylla) for most of its food (Banko et al., 2009, 2002a). Māmane is an endemic, leguminous tree that was once more widely distributed but is now primarily found in dry montane and subalpine habitats on the islands of Hawai'i and Maui. Specialization on 
māmane dramatically increases the palila's vulnerability to extinction, especially in the face of global climate change and multiple threats from invasive species. Palila cannot persist long where māmane is sparsely distributed or confined to a narrow band of elevation (Scott et al., 1984; van Riper et al., 1978), because the birds track seed pods as they ripen seasonally along an elevation gradient (Banko et al., 2002a, 2002b; Hess et al., 2001). The range of elevation over which māmane occurs has been truncated at both the lower and upper margins by nearly 200 years of browsing by introduced ungulates, which continue to degrade the remaining habitat (Banko et al., 2009). Another factor affecting palila habitat is drought, and a trend towards drier climatic conditions seems to be developing (Giambelluca and Luke, 2007; Loope and Giambelluca, 1998). Palila survival and reproduction decline during drought, when māmane pod production is reduced (Banko et al., 2002a; Lindsey et al., 1997).

Range size is a powerful predictor of extinction risk among birds (Harris and Pimm, 2008), and montane species are most vulnerable to the effects of climate change (Şekercioğlu et al., 2012, 2008). Palila are at risk from both factors because they are now entirely restricted to high-elevation habitats and they occupy one of the smallest ranges of any bird in Hawai'i (Gorresen et al., 2009). Historically, palila were found in woodlands dominated by māmane and naio (Myoporum sandwicense), another common endemic tree, on three of the five volcanoes of Hawai'i Island (Fig. 1). Nevertheless, habitat loss and degradation, mostly due to cattle ranching and introduced feral ungulates (Scowcroft, 1983), has reduced the palila's range to only $5 \%$ of its historical extent, palila have disappeared from all areas outside the largest remaining forest fragment on the southwestern slope of Mauna Kea (Banko et al., 2009; Leonard et al., 2008).

Introduced ungulates are universal transformers of vegetation structure and composition, and they can impact biodiversity in a number of ways (Spear and Chown, 2009) within their native continental ranges (Holmes et al., 2009), on islands near continents (Martin et al., 2010), and especially on remote oceanic islands (Caujapé-Castells et al., 2010; Loope et al., 1988). Habitat degradation by introduced ungulates has broadly affected Hawaiian bird communities (Banko and Banko, 2009; Pratt and Jacobi, 2009; Scott et al., 1986) and has been the most important factor driving the palila's historical range contraction and population decline (Banko et al., 2009). Since the early 1800s, cattle (Bos taurus), goats (Capra hircus), and sheep (Ovis aries and, more recently, mouflon [O. gmelini musimon] and their hybrids) have roamed widely through the palila's range, killing or damaging trees and shrubs, removing seedlings, and exacerbating erosion (Hartt and Neal, 1940; Hess and Banko, 2011; Warner, 1960). Cattle, goats, and sheep prefer māmane over non-native species (Giffin, 1980, 1976), and long-term browsing has reduced the cover and regeneration of māmane as well as other tree and shrub species in palila habitat (Scowcroft, 1983; Scowcroft and Giffin, 1983). Large gaps created in māmane woodland by ungulates have been invaded by grasses and other weeds (Banko et al., 2009; Hess et al., 1999), greatly increasing the threat of fire (Thaxton and Jacobi, 2009). Efforts to reduce ungulate populations during the 1930s and 1940s and since the 1980s have resulted in the episodic regeneration of māmane (Hess et al., 1999; Scowcroft and Conrad, 1988). Nevertheless, forest recovery has been limited and intermittent because widespread browsing has continued (Banko et al., 2009; Hess and Banko, 2011; Hess et al., 1999).

In addition to browsing ungulates, other invasive species and climate change threaten palila and Mauna Kea's subalpine bird community (Banko et al., 2009). Climate change is expected to modify Hawaiian forest bird habitats, food webs, and the distributions of invasive threats in ways that are only recently being considered (Loope and Giambelluca, 1998; Pratt et al., 2009). Climatic trends indicate that the palila's habitat will become even drier (Cao et al., 2007; Chu et al., 2010; Chu and Chen, 2005; Giambelluca and Luke, 2007), which will likely affect vegetation structure and composition (Juvik et al., 2011; Lohse et al., 1995; Loope and Giambelluca, 1998) and further reduce habitat carrying capacity. Unfortunately, the effects of increased drought will be compounded by browsing, pathogens, competition from invasive weeds, and other stressors (Banko et al., 2009).

To assess how the subalpine bird community may be responding to recent weather patterns, we evaluated population trends of palila and other passerines in relation to rainfall and drought since 1998. This analysis is the first to include all passerines across a major portion of Palila Critical Habitat since the Hawai'i Forest Bird Survey program was initiated (Scott et al., 1986). Although we focus our attention on the palila due to its significance to conservation biology and policy, trends of the other species provide important context for understanding how species with divergent life histories respond to drought and habitat degradation. Data on weather conditions and on the ecology of palila, māmane, and naio were not collected continuously throughout the 14-year study period, but information overlapped sufficiently to allow us to explore major relationships. Additionally, earlier studies provide a basis for understanding how drought affects the breeding and survival of passerines (Banko et al., 2002a; Lindsey et al., 1997; Pratt et al., 1997) and the phenology and productivity of māmane and naio (Banko et al., 2002b). Although palila are the only birds that feed on māmane seeds, a number of other passerines forage in māmane for nectar and arthropods, including the ubiquitous, native Hawaii 'amakihi (Hemignathus virens virens) and the widespread, introduced Japanese white-eye (Zosterops japonicus), both generalist foragers. Additionally, two species of Hawaiian honeycreepers, the 'i'iwi (Vestiaria coccinea) and 'apapane (Himatione sanguinea), visit subalpine Mauna Kea seasonally to feed on māmane nectar (Banko et al., 2002b; Hess et al., 2001). Palila and other bird species, notably the native generalist insectivore, Hawai'i 'elepaio (Chasiempis sandwichensis), and the introduced generalist frugivore-insectivore, red-billed leiothrix (Leiothrix lutea), also forage in naio, which is widespread on the southwestern slope of Mauna Kea (Scott et al., 1986). Although ungulates browse less on naio than they do on māmane, we have observed that drought impacts are more severe on naio than they are on māmane. Therefore, prolonged drought is likely to affect other passerines in addition to palila. Our results provide insights about the roles of climate change and invasive species in shaping Hawaiian forest bird communities above the range of introduced mosquito-borne diseases, which have major impacts elsewhere (Scott et al., 1986). Our study also highlights the importance of increasing the carrying capacity of all forest bird habitats to help populations survive multiple environmental challenges.

\section{Methods}

\subsection{Study area}

The survey area consisted of $64.4 \mathrm{~km}^{2}$ of subalpine dry forest between 1800 and $2900 \mathrm{~m}$ elevation on the southwestern slope of Mauna Kea Volcano, Hawai'i Island (Fig. 1). We refer to it as the "core" habitat or area of the species because it has supported over $95 \%$ of the palila population since standardized surveys began in 1980 (Scott et al., 1984). The climate is cool and dry. Annual mean temperatures range between $9^{\circ}$ and $13^{\circ} \mathrm{C}$; rainfall averages $511 \mathrm{~mm}$ annually and falls mostly during heavy winter storms, but cloud water intercepted by vegetation ("fog-drip") contributes additional precipitation (Juvik et al., 1993). The vegetation is dom- 


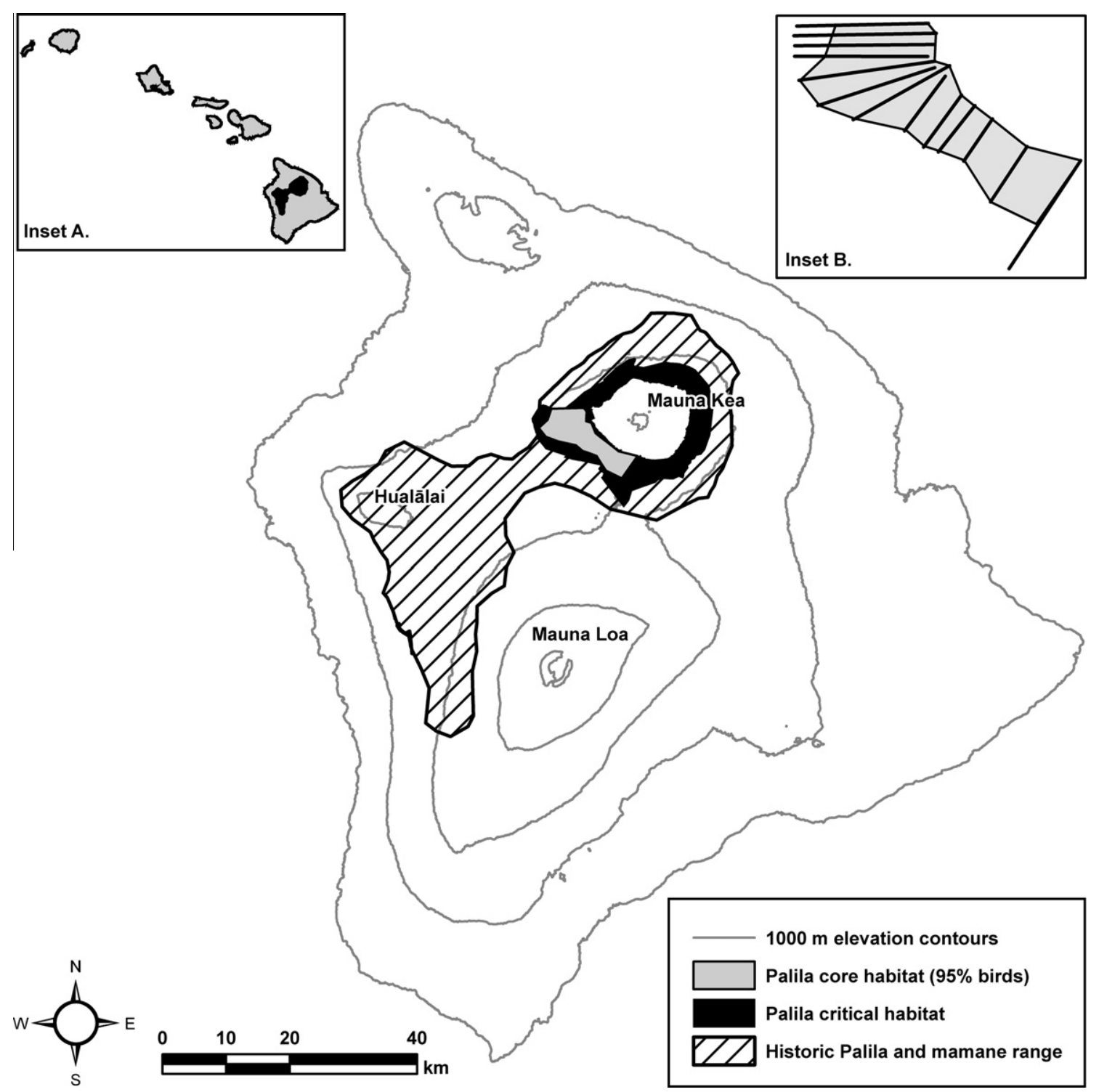

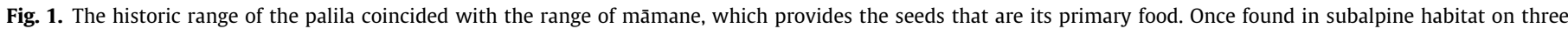

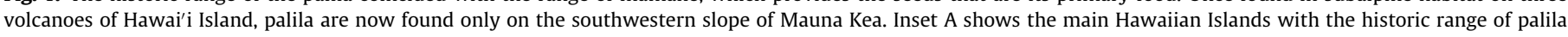
shown in black. Inset B shows the core palila habitat with survey transects.

inated by two native tree species, māmane and naio (Banko et al., 2002b; Hess et al., 1999).

\subsection{Survey methods}

We annually surveyed all passerine species during 6-min counts at 355-418 stations along 13 transects in the core habitat during 1998-2011 (Fig. 1, Supplementary material A.1.1). Because of their high conservation profile, density estimates (birds $/ \mathrm{km}^{2}$ ) of palila were calculated from point-transect sampling data using program DISTANCE (Supplementary material A.1.1). To allow for comparisons among all species, including those for which there were too few detections to reliably estimate densities, we calculated an annual index of abundance as the average number of birds per station (total detections/total stations). We characterized trends in the annual mean number of birds per station for each species based on the magnitude of change indicated by a best-fit linear model (Camp et al., 2008). We also used this method to characterize trends in the number of stations at which species were detected each year.

\subsection{Drought index, habitat degradation, and evaluation of impacts}

We developed an index to characterize the extent and severity of drought in the survey area using available data from the U.S. Drought Monitor website that modeled the distribution of five qualitative categories of drought projected to occur on Hawai'i Island each week for the period January 2000-April 2011. (Supplementary material A.1.2). To this dataset, we applied a GIS template to calculate the proportion of our study area covered by each category of drought, which included "abnormally dry," "moderate drought," "severe drought," "extreme drought," and "exceptional drought" in addition to "no drought." We then multiplied the proportional area by the rank (values 1-4 for drought and -1 for no drought) of the drought category that covered it to produce a score. Scores were combined into a composite score representing drought severity over the entire study area for each week, and these results were then averaged to produce monthly scores that were analyzed descriptively to characterize seasonal or annual environmental conditions.

We analyzed recent (1997-2010) and long-term (1940-1977) rainfall data from two sites, $\mathrm{Pu}^{\prime} \mathrm{u}$ Lā'au and Halepōhaku (National 
Climatic Data Center, Hawai'i Division of Forestry and Wildlife; Supplementary material A.1.3) to determine the degree to which the distribution of rainfall supported the results of the drought index and to provide additional context for understanding bird population trends.

To evaluate the impact of drought on māmane seed pod production during the palila breeding season, we estimated monthly pod abundance on 335 māmane trees in the survey area during AprilAugust of 2000 through 2004 (Supplementary material A.1.4).

During 1999-2001, we evaluated vegetation structure, māmane regeneration, and damage from sheep within the core habitat adjacent to bird survey stations. We measured tree canopy dimensions, counted saplings (0.2-2.0 m height), and recorded the incidence of browsed branch tips or bark striping on 281 plots measuring $40 \times 40 \mathrm{~m}$.

\section{Results}

\subsection{Palila population estimate and trend}

Estimates of the palila population during the 14-year period peaked at 5952 (95\% CI: 5022-7073) in 2003 then declined for eight consecutive years to 1263 (938-1613) in 2011 (Fig. 2, Supplementary Table A2). From 2003 to 2011, population estimates declined each year by an average of $586 \pm 105.7$ birds (mean $\pm \mathrm{SE}$; range 90-938) for a mean annual loss of $17 \% \pm 3.5$ (range $3-37 \%$ ) or $79 \%$ overall.

During the 1998-2010 surveys, palila were detected in $43.3 \mathrm{~km}^{2}(67 \%)$ of the core area $\left(64.4 \mathrm{~km}^{2}\right)$, with detections being broadly distributed in the northern portion of the core habitat and in a long tail across the upper elevations to the south (Supplementary Fig. A1). In 2011, palila detections were limited to $14.6 \mathrm{~km}^{2}(23 \%)$ of the core habitat.

\subsection{Community-wide population trends}

We detected 20 passerine species over the course of the 1998 2011 surveys (Table 1 ). Nine species, including the sky lark (Alauda arvensis), were detected in all 14 years and were relatively widespread. We excluded the sky lark from further analyses because its conspicuous, aerial displays made it exceptionally detectable, and therefore inappropriate to compare with species that were mainly detected in trees and shrubs.

The most abundant species overall (Table 1 ) were Hawai'i 'amakihi (5.9 birds/station), house finch (Carpodacus mexicanus; 1.75 birds/station), and Japanese white-eye (1.14 birds/station). The palila was the fourth most common species, averaging 0.66 birds/station, followed by the red-billed leiothrix ( 0.18 birds/sta-

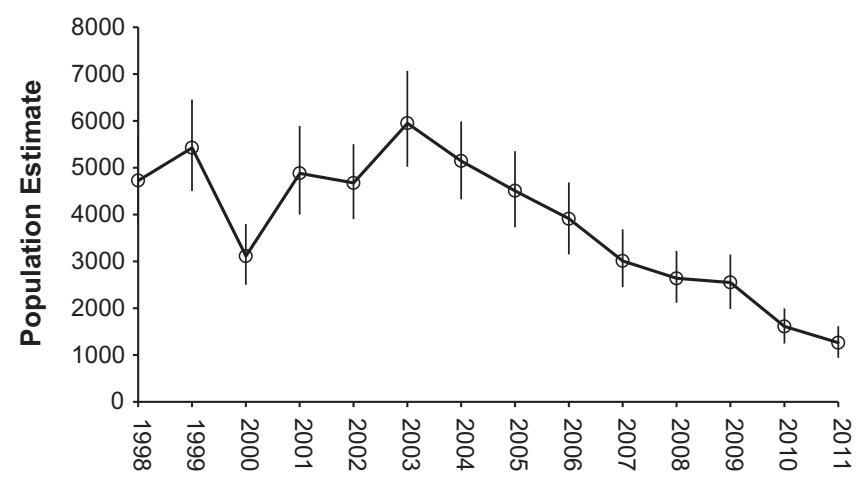

Fig. 2. Annual palila population estimates and $95 \%$ confidence intervals derived from point-transect surveys since 1998, when for the first time all passerine species were surveyed instead of select species only and when survey effort was increased by adding new transects. tion) and Hawai'i 'elepaio ( 0.13 birds/station). Low numbers of other species were detected in 1-13 surveys (Table 1 ). The Japanese bush-warbler (Cettia diphone) was first detected on the 2006 survey, then intermittently on three later surveys. The 'akiapōlä'au was detected only in 1998.

Of the six most common species, population declines were evident for palila, Hawai'i 'elepaio, and Japanese white-eye, but annual estimates of the other species varied considerably and resulted in no apparent trend (Table 1, Supplementary Fig. A2). Declines in the native seasonal visitors, 'apapane and ' $i$ 'iwi, were the most notable trends among the less abundant species. Changes in the number of survey stations at which species were detected generally followed trends in species abundance (Supplementary Table A3). Palila were detected at $34 \%$ of the stations $(n=373)$ surveyed in 1998 , and $42 \%$ of stations $(n=421)$ in 2003 , but only $18 \%$ of stations $(n=411)$ surveyed in 2011. In contrast, the proportion of stations occupied by Hawai'i 'amakihi declined very slightly from nearly 100\% during 1998-2000 to 96\% in 2011.

\subsection{Drought and rainfall patterns}

All categories of drought severity, including "no drought," were recorded during 2000-2010, but dry conditions were pervasive (Supplementary Table A4). Drought conditions occurred during $98(74 \%)$ of 132 months, with drought recorded in 52 of 54 months after June 2006. The longest period without drought was 14 months, which encompassed 2002, but other interruptions lasted only 1-7 months. Drought was most severe in 2009, followed by 2010. Drought occurred in all months of the year but seemed on average more severe during summer and early fall (June-October).

Historical and recent rainfall totals were highly variable, providing weak and inconsistent support for the results of the drought index (Supplementary material A.2.3; Tables A5 and A6). Nevertheless, since 1997, annual rainfall at both sites was lower than normal nearly twice as often as it was higher than normal when compared with the historical data, indicating that this period was unusually dry. Moreover, monthly patterns of rainfall generally agreed with the results of the drought index. Mean monthly rainfall since 1997 fell below historical means in $65 \%$ and $71 \%$ of months at Pu'u Lā'au and Halepōhaku, respectively (Supplementary Table A7). The months of lowest rainfall were June-October, which were $39 \%$ and $52 \%$ drier than November-May for Pu'u Lä'au and Halepōhaku, respectively (Supplementary Table A5).

\subsection{Effect of drought on māmane pod abundance and palila nesting}

Drought affected the average number of pods per tree per month during 2000-2004, when data for estimating both the drought index and pod abundance were available. Contrasting the wettest and driest years, trees $(n=583)$ produced an average of 148 ( $\pm 16.7 \mathrm{SE}$ ) pods per month during the palila breeding season (April-August) in the drought-free year of 2002; but in 2003, the driest year, trees $(n=469)$ produced $76 \%$ fewer pods ( $35 \pm 7.4 \mathrm{SE}$ ) (Supplementary Fig. 3).

\subsection{Habitat structure and carrying capacity}

We estimated that about 731,948 māmane and 730,516 naio trees populated the core area during 1999-2001. The mean cover of all tree species was $22.3 \%$, of which māmane accounted for $7.8 \%$ and naio accounted for $14.4 \%$. The mean height of 5110 māmane trees was $3.83 \mathrm{~m}$ (1.27 m SD). We recorded māmane regeneration in $95.0 \%$ of plots, but high sapling densities (>100 per ha) occurred in only $28.5 \%$ of plots. Evidence of browsing or bark striping by sheep was recorded in $59.1 \%$ of plots. The total number of 
Table 1

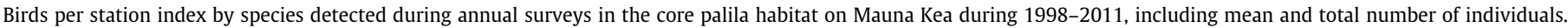

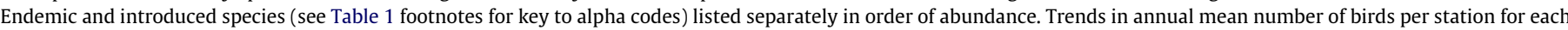

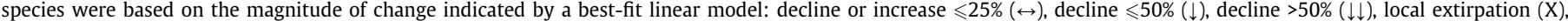
insufficient data (NA). Population increases $>25 \%$ were not observed.

\begin{tabular}{|c|c|c|c|c|c|c|c|c|c|c|c|c|c|c|c|c|c|}
\hline & 1998 & 1999 & 2000 & 2001 & 2002 & 2003 & 2004 & 2005 & 2006 & 2007 & 2008 & 2009 & 2010 & 2011 & Mean & Total & Trend \\
\hline \multicolumn{18}{|c|}{ Endemic species $^{\mathrm{a}}$} \\
\hline HAAM & 7.188 & 7.099 & 5.751 & 6.080 & 7.487 & 4.667 & 5.882 & 5.589 & 4.912 & 4.998 & 5.421 & 7.337 & 4.664 & 6.192 & 5.948 & 33,838 & $\leftrightarrow$ \\
\hline PALI & 0.842 & 0.896 & 0.545 & 0.783 & 0.776 & 1.043 & 0.892 & 0.748 & 0.682 & 0.492 & 0.444 & 0.451 & 0.367 & 0.290 & 0.661 & 3,861 & $\downarrow \downarrow$ \\
\hline HAEL & 0.107 & 0.164 & 0.266 & 0.217 & 0.167 & 0.154 & 0.156 & 0.067 & 0.063 & 0.096 & 0.079 & 0.101 & 0.058 & 0.102 & 0.128 & 746 & $\downarrow \downarrow$ \\
\hline APAP & 0.038 & 0.062 & 0.084 & 0.279 & 0.124 & 0.033 & 0.111 & 0.045 & 0.008 & 0.005 & 0.095 & 0.022 & 0.032 & 0.034 & 0.069 & 395 & $\downarrow \downarrow$ \\
\hline IIWI & 0.051 & 0.051 & 0.086 & 0.038 & 0.078 & 0 & 0.017 & 0.010 & 0.003 & 0 & 0 & 0 & 0.005 & 0 & 0.024 & 142 & $\downarrow \downarrow$ \\
\hline AKIP & 0.003 & 0 & 0 & 0 & 0 & 0 & 0 & 0 & 0 & 0 & 0 & 0 & 0 & 0 & NA & 1 & $\mathrm{X}$ \\
\hline \multicolumn{18}{|c|}{ Introduced species ${ }^{\mathrm{b}}$} \\
\hline HOFI & 1.279 & 1.380 & 1.382 & 2.442 & 2.469 & 1.192 & 1.618 & 1.800 & 1.644 & 1.885 & 2.368 & 1.496 & 1.659 & 1.939 & 1.754 & 9,771 & $\leftrightarrow$ \\
\hline JAWE & 1.751 & 1.385 & 0.834 & 1.385 & 1.517 & 1.382 & 0.974 & 1.176 & 1.184 & 1.885 & 0.750 & 0.530 & 0.898 & 0.324 & 1.141 & 6,384 & $\downarrow \downarrow$ \\
\hline SKLA & 0.692 & 0.818 & 0.855 & 0.901 & 0.741 & 0.451 & 0.707 & 0.808 & 0.768 & 0.986 & 0.998 & 0.624 & 0.353 & 0.645 & 0.739 & 4,148 & $\leftrightarrow$ \\
\hline RBLE & 0.359 & 0.124 & 0.065 & 0.050 & 0.078 & 0.290 & 0.019 & 0.166 & 0.184 & 0.417 & 0.373 & 0.190 & 0.204 & 0.022 & 0.182 & 1,029 & $\leftrightarrow$ \\
\hline YFCA & 0.064 & 0.099 & 0.037 & 0.071 & 0.169 & 0.069 & 0.050 & 0.045 & 0.182 & 0.044 & 0.016 & 0.041 & 0.144 & 0.027 & 0.076 & 429 & $\leftrightarrow$ \\
\hline NOCA & 0.067 & 0.108 & 0.077 & 0.028 & 0.066 & 0.021 & 0.060 & 0.036 & 0.068 & 0.044 & 0.148 & 0.063 & 0.010 & 0.005 & 0.057 & 311 & $\downarrow$ \\
\hline NOMO & 0.024 & 0.016 & 0.005 & 0.005 & 0.030 & 0.024 & 0.012 & 0.021 & 0.015 & 0.026 & 0.025 & 0.022 & 0.010 & 0 & 0.017 & 97 & $\leftrightarrow$ \\
\hline AFSI & 0.013 & 0 & 0.002 & 0.017 & 0.027 & 0.038 & 0.005 & 0.002 & 0.053 & 0.019 & 0.012 & 0 & 0.017 & 0 & 0.015 & 79 & $\leftrightarrow$ \\
\hline MELT & 0.024 & 0.028 & 0.026 & 0.007 & 0.014 & 0.002 & 0.002 & 0.002 & 0.005 & 0.002 & 0.002 & 0.048 & 0.005 & 0 & 0.012 & 69 & $\downarrow \downarrow$ \\
\hline JABW & 0 & 0 & 0 & 0 & 0 & 0 & 0 & 0 & 0.003 & 0.005 & 0 & 0.048 & 0 & 0.012 & 0.005 & 28 & NA \\
\hline COMY & 0.008 & 0.007 & 0.026 & 0 & 0 & 0.002 & 0.002 & 0 & 0.008 & 0.002 & 0 & 0 & 0 & 0 & 0.004 & 23 & NA \\
\hline HOSP & 0 & 0.014 & 0.009 & 0.007 & 0.009 & 0.002 & 0 & 0.005 & 0 & 0 & 0 & 0 & 0 & 0 & 0.003 & 20 & NA \\
\hline YBCA & 0 & 0 & 0 & 0 & 0 & 0 & 0 & 0 & 0.015 & 0 & 0 & 0 & 0 & 0 & 0.001 & 6 & NA \\
\hline NUMA & 0 & 0 & 0 & 0 & 0.002 & 0.007 & 0 & 0 & 0 & 0 & 0 & 0 & 0.005 & 0 & 0.001 & 5 & NA \\
\hline
\end{tabular}

a AKIP ('akiapōlā'au, Hemignathus munroi, Drepanidinae); APAP ('apapane, Himatione sanguinea, Drepanidinae); HAAM (Hawai'i 'amakihi, Hemignathus virens, Drepanidinae); HAEL (Hawai'i 'elepaio, Chasiempis sandwichensis, Monarchidae); IIWI ('i'iwi, Vestiaria coccinea, Drepanidinae); PALI (palila, Loxioides bailleui, Drepanidinae).

b AFSI (African silverbill, Lonchura cantans, Estrildidae); COMY (common myna, Acridotheres tristis, Sturnidae); HOFI (house finch, Carpodacus mexicanus, Fringillidae); HOSP

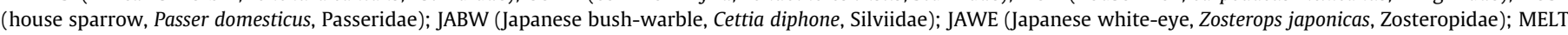

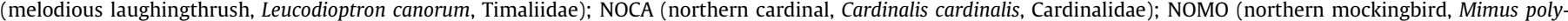

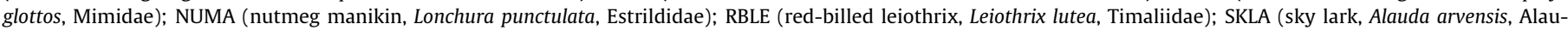
didae); YBCA (yellow-billed cardinal, Paroaria capitata, Emberizidae); YFCA (yellow-fronted canary, Serinus mozambicus, Fringillidae).

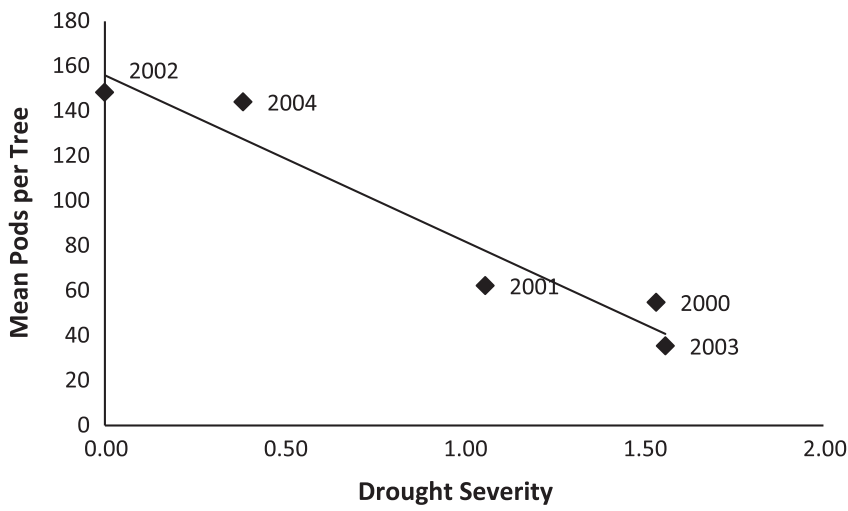

Fig. 3. Linear relationship $\left(y=-73.772 \times+155.9, R^{2}=0.9338, P=0.007\right)$ between mean māmane pod production per tree and drought severity. Māmane trees produced fewer pods in years when drought was more severe, as indicated by high annual mean drought index values. Monthly pod production was estimated for the palila breeding season (April-August).

palila counted per station during 1998-2011 was significantly correlated to the amount of māmane cover in adjacent vegetation plots $\left(P<0.001 ;\right.$ correlation $=0.321 ; \quad r^{2}=0.103 ; \quad$ slope $=0.428$ detections/percent cover).

\section{Discussion}

\subsection{Decline of specialist species}

The $79 \%$ decline in palila population estimates since 2003 is unprecedented in 32 years of monitoring (Banko et al., 2009; Jacobi et al., 1996). Also of concern is the $58 \%$ decline in the proportion of survey stations with palila during 2003-2011. Palila were detected in $<15 \mathrm{~km}^{2}$ of habitat in 2011, underscoring their vulnerability to local catastrophes. At the present rate of decline, the species could be extinct very soon (Leonard et al., 2008), and even under improved environmental conditions, this diminished population will be slow to rebound due to low reproductive rates of wild birds and the limited ability to release captive-reared birds into the wild (Banko et al., 2009). Furthermore, absent effective management, relict populations of Hawaiian passerines have never been recovered and many have dwindled to extinction (Banko et al., 2001; Gorresen et al., 2009). For example, in addition to the recent disappearance of the 'akiapōlā'au from subalpine Mauna Kea, decades have passed since the endangered Hawai'i 'àkepa (Loxops coccineus coccineus), another specialist, and the endangered Hawai'i creeper (Oreomystis mana) have been reported in māmane-naio woodland (Banko, 1984a; Scott et al., 1986; Snetsinger, 1995). Due to low reproductive capacity, reduced tolerance of ecological perturbations (Banko and Banko, 2009; Şekercioğlu et al., 2012), and long-term, widespread habitat deterioration, this downward trajectory of specialists suggests that their recovery will be slow, even after effective management is applied.

\subsection{Trends of non-specialist and uncommon species}

Despite their overall resiliency to disturbance, populations of some non-specialist species also declined on Mauna Kea, including the Hawai'i 'elepaio and the Japanese white-eye. Additionally, both species declined in the proportion of stations where they were detected, indicating that environmental stress is affecting some native and introduced generalists. Nevertheless, the generalist Hawai'i 'amakihi declined little in abundance or distribution, indicating a high degree of resilience. 
Small populations are expected to decline rapidly under deteriorating environmental conditions, although trends in small populations are difficult to detect (Camp et al., 2009). Nevertheless, our results indicated that small, local populations of many introduced species (Table 1) persisted during the drought years. It seems unlikely that these populations were sustained solely by immigrants because potential source areas were also affected by drought. Nevertheless, some immigration apparently occurred during the drought because the introduced Japanese bush-warbler, a small insectivore associated more with dense understory vegetation (Foster, 2009) than with dry woodland, established a small foothold in the study area, which is testament to the ability of some generalists to cope with harsh environmental conditions. In contrast to these introduced resident species, seasonal movement to the māmane forest by native nectar-feeders declined during the survey period.

\subsection{Impacts of drought}

The drought index provided relatively consistent evidence of the prolonged and extreme episodes of dry conditions that we observed on Mauna Kea. Although monthly rainfall patterns generally supported the results of the drought index, annual rainfall was less congruent, suggesting that localized storms distributed rainfall unevenly across the landscape. During normal to wet periods, for example, rain gauge totals at similar elevations on the southwestern slope of Mauna Kea varied by over $300 \mathrm{~mm}$, although during drier periods they tended to vary less (Juvik et al., 1993). Nevertheless, rainfall patterns at Halepōhaku were more congruent with the drought index and our observations of wilted vegetation, dry soil, and the poor condition of the habitat in general. Although it was not measured, fog-drip can become the dominant form of precipitation under trees during periods of unusually low rainfall (Juvik et al., 1993), and fog-drip's contribution to canopy throughfall probably moderated drought impacts somewhat during our study.

The dry conditions that normally prevail in subalpine Mauna Kea (Juvik et al., 1993) influence the vegetation structure and composition (Hess et al., 1999), but the long-term effects of severe, multi-year drought on plant vigor, productivity, and recruitment have yet to be evaluated. Long periods of abnormally dry weather could be expected to reduce tree cover and increase grass cover (Lohse et al., 1995; Loope and Giambelluca, 1998), and monitoring would identify the extent to which māmane is being affected by drought.

The short-term effects of severe drought on passerine populations have been noted before on Mauna Kea (Lindsey et al., 1997), but results of our study allow consideration of the chronic drought impacts. Drought likely contributed heavily to the recent decline of palila, although effects on most other species were less pronounced or consistent over time. The palila population estimate peaked in 2003, just after the longest period of relatively normal weather during the study period, which was 14 months (November 2001-December 2002). The population declined each year thereafter, when drought conditions were interrupted on only six occasions, each lasting from 1 to 7 months. Dry conditions were strongly associated with lower māmane pod production, and because palila survival and reproduction are reduced when pods are scarce (Lindsey et al., 1997, 1995; Pratt et al., 1997), fewer palila likely nested during the drought. Nevertheless, the relationship between nesting attempts and pod availability is weak (Banko et al., 2009), suggesting that age structure, sex ratio, or other factors also might influence annual nesting activity.

Among the common species that seemed most tolerant of drought conditions were those that forage mainly in grass and on the ground for seeds and insects: the house finch, yellow-fronted canary (Serinus mozambicus), and sky lark. Although Hawai'i 'ama- kihi may have avoided the graver consequences of drought by foraging in a variety of shrubs and trees, the Hawai'i 'elepaio and especially the Japanese white-eye fared less well. The decline in Japanese white-eye numbers could be the result of competition with the more abundant and somewhat larger Hawai'i 'amakihi during periods of low food availability and harsh environmental conditions.

\subsection{Effects of browsing on habitat carrying capacity and implications for recovery}

Despite the serious, immediate impacts of drought on palila demography, the most important, long-term manageable threat to the population is habitat degradation by feral sheep and mouflon sheep (Banko et al., 2009; Scott et al., 1984; U.S. Fish and Wildlife Service, 2006). Over many decades, browsing has changed the structure and composition of montane and subalpine vegetation on Mauna Kea by removing seedlings, wounding saplings and trees, and reducing tree and shrub cover (Hess et al., 1999; Scowcroft, 1983; Scowcroft and Giffin, 1983; Scowcroft and Sakai, 1983). Although browsing presumably depletes the non-structural carbohydrate reserves of all size classes of māmane trees, it is the seedlings, saplings, and small trees that should be especially vulnerable due to their shallow, less developed root systems, greater proportion of leaf biomass, and reduced concentrations of non-structural carbohydrates (Niinemets, 2010). On average, māmane measured during 1999-2001 were less than 4-m tall, suggesting that this relatively young population of trees should be highly susceptible to browsing, drought, and other stressors compared to a population of older, larger trees. Additionally, browsing likely reduces the tolerance of māmane and other species to the physiological burdens presumably imposed by drought, temperature extremes (Juvik et al., 1993), pathogens (Gardiner and Trujillo, 2001), and competition from invasive grasses and a variety of other weeds (Banko et al., 2009; Williams, 1994). The ability of trees to tolerate multiple chronic stress factors is rare (Niinemets, 2010); therefore, tree vigor and productivity should increase when browsing and other manageable sources of stress are alleviated.

Sheep have long been hunted on Mauna Kea, and during 19982010 nearly 11000 sheep were removed from Palila Critical Habitat by a combination of public hunting (54\%) and aerial shooting (46\%) (Hawai'i Division of Forestry and Wildlife unpublished data). The impact of this program on the unmonitored population of sheep is unknown, but this level of removal has not prevented widespread, severe browse damage from continuing and it likely falls well below the annual rate of removal needed for eradication. Nevertheless, previous work (Scowcroft and Conrad, 1988) and our vegetation surveys indicate that robust habitat recovery is possible in the absence of browsing. Although māmane crown cover was very low during 1999-2001, many of the trees we encountered were small (young) and saplings were widespread, if sparsely distributed. Even during the recent drought, māmane seedling density was observed to be 77.7 seedlings per ha only 6 years after browsers were eliminated from within a recently constructed ungulate exclosure, whereas 10.9 seedlings per ha were recorded outside the exclosure (Hawai'i Division of Forestry and Wildlife unpublished data).

We can expect a long lag before palila fully benefit from forest recovery, given that palila are more common in areas with greater crown cover, taller trees, and a higher proportion of native plants in the understory (Scott et al., 1984). Our finding that palila detections increased with māmane cover confirms this relationship and establishes a basis for modeling the response of palila to improved habitat carrying capacity. For example, doubling the fraction of māmane tree cover from $7.8 \%$, which is the mean for the core area, to $15.6 \%$ should yield $26 \%$ more palila detections during surveys. As 
tree size increases over time, palila detections should increase even more. Nevertheless, a rapid response to sheep eradication could be expected as lower tree branches re-sprout and canopy volume increases, yielding more food for palila and other birds (Banko et al., 2009). Given that most trees are $<4 \mathrm{~m}$ in height and that browsing extends to at least $1 \mathrm{~m}$ height, tree canopy volume could quickly increase by roughly $25 \%$ after removing sheep.

In the long-term, increased tree cover through ungulate eradication and habitat restoration will result in higher soil moisture through increased cloud water interception and canopy throughfall (Juvik et al., 1993) as well as less grass cover and reduced fire risk (Hess et al., 1999; Thaxton and Jacobi, 2009). At a global scale, invasive grasses pose serious threats to ecosystems through competition with native vegetation for water and nutrients and by escalating fire risks through the accumulation of fine fuels and the promotion of grass-fire cycles (D'Antonio and Vitousek, 1992). On Mauna Kea, invasive grasses and other weeds compete for water and nutrients with māmane and other native trees and shrubs, thereby adding to the stress of drought as well as suppressing regeneration and increasing fire threats (Cabin et al., 2000; Hess et al., 1999; Williams, 1994). Reducing grass cover by promoting tree cover and potentially by the strategic application of herbicide could also, therefore, boost habitat carrying capacity. Results of our vegetation survey indicate that nearly 1.5 million māmane and naio trees are available to palila and other birds in the core habitat, yet many more trees are needed to sustain bird populations during prolonged drought.

Without effective and timely intervention, demographic and stochastic factors may further impede recovery of the dwindling palila population. Priority action was long ago (1979) and repeatedly $(1987,1998)$ mandated by court order: permanently remove introduced browsing ungulates from Palila Critical Habitat (Juvik and Juvik, 1984; U.S. Fish and Wildlife Service, 2006). To help accomplish this goal, the original fence built in 1936 to protect Mauna Kea Forest Reserve from introduced ungulates is being replaced by an $82-\mathrm{km}$, ungulate-proof fence around most of Critical Habitat and a draft plan to eradicate sheep and goats has been completed.

\section{Conclusion}

The disappearance of specialist feeders, most recently the 'akiapōlā'au, and the sharp decline in palila numbers underscore the urgency of protecting the forest bird community of Mauna Kea. Without informed, effective management, conservation options diminish as threatened populations decline and habitat conditions deteriorate. Long-term and continuing damage to habitat by ungulate browsing is being compounded by severe, prolonged drought that may be a consequence of climate change. Despite their rate of decline and imposing threats to their survival, the palila is a species for which long-term persistence, if not recovery, is a realistic goal, but only if habitat carrying capacity can be increased in time and over a sufficiently large area. Management will also benefit other native forest bird species affected by drought, and the effectiveness of measures taken should be observed first in the trends of generalist species, which will likely respond relatively quickly to improving conditions. Our results point to the value of long-term ecological studies and population monitoring in areas where climate change is exacerbating the impacts of invasive species on endangered species and bird communities generally.

\section{Acknowledgements}

This research was made possible thanks to support from the Federal Highway Administration, U.S. Army Garrison Hawai'i,
Hawai'i Division of Forestry and Wildlife (DOFAW), U.S. Fish and Wildlife Service (USFWS), American Bird Conservancy, and U.S. Geological Survey (USGS) wildlife research programs. For assistance in the field we are grateful to staff of the USGS Pacific Island Ecosystems Research Center, particularly G. Beauprez, C. Cole (Murray), S. Hess, and L. Johnson; staff of the DOFAW Mauna Kea Forest Restoration Project; and many volunteers and staff from a variety of other organizations. We thank D. Miskus for providing data from the U.S. Drought Monitor and P. Berkowitz for GIS assistance. USFWS and DOFAW provided permits and access to study sites. We thank Eben Paxton and three anonymous reviewers for their suggestions for improving the manuscript. Any use of trade, firm, or product names is for descriptive purposes only and does not imply endorsement by the U.S. Government.

\section{Appendix A. Supplementary material}

Supplementary data associated with this article can be found, in the online version, at http://dx.doi.org/10.1016/j.biocon.2012.07. 013.

\section{References}

Banko, P.C., David, R.E., Jacobi, J.D., Banko, W.E., 2001. Conservation status and recovery strategies for endemic Hawaiian birds. Stud. Avian Biol. 22, 359-376.

Banko, P.C., Johnson, L., Lindsey, G.D., Fancy, S.G., Pratt, T.K., Jacobi, J.D., Banko, W.E. 2002a. Palila (Loxioides bailleui), No. 679. In: Poole, A., Gill, F. (Eds.), The Birds of North America, The Birds of North America Inc., Philadelphia.

Banko, P.C., Oboyski, P.T., Slotterback, J.W., Dougill, S.J., Goltz, D.M., Johnson, L., Laut, M.E., Murray, C., 2002b. Availability of food resources, distribution of invasive species, and conservation of a Hawaiian bird along a gradient of elevation. J. Biogeogr. 29, 789-808.

Banko, P.C., Banko, W.E., 2009. Evolution and ecology of food exploitation. In: Pratt T.K., Atkinson, C.T., Banko, P.C., Jacobi, J.D., Woodworth, B.L. (Eds.), Conservation Biology of Hawaiian Forest Birds: Implications for Island Avifauna. Yale University Press, New Haven, pp. 159-193.

Banko, P.C., Brinck, K.W., Farmer, C., Hess, S.C., 2009. Palila. In: Pratt, T.K., Atkinson, C.T., Banko, P.C., Jacobi, J.D., Woodworth, B.L. (Eds.), Conservation Biology of Hawaiian Forest Birds: Implications for Island Avifauna. Yale University Press, New Haven, pp. 513-529.

Banko, W.E., 1984. History of Endemic Hawaiian Birds, Part 1: Population Histories - Species Accounts, Forest Birds: 'ākepa and po'o uli. Avian History Report 8C. Cooperative National Park Resources Studies Unit, University of Hawaii at Manoa, Honolulu.

Banko, W.E., Banko, P.C., 2009. Historic extinction and decline. In: Pratt, T.K. Atkinson, C.T., Banko, P.C., Jacobi, J.D., Woodworth, B.L. (Eds.), Conservation Biology of Hawaiian Forest Birds: Implications for Island Avifauna. Yale University Press, New Haven, pp. 25-58.

BirdLife International, 2000. Threatened Birds of the World. Lynx Edicions and BirdLife International, Barcelona and Cambridge.

Birdlife International, 2011. Species Factsheet for Palila Loxioides bailleui. <http:/ www.birdlife.org/datazone/speciesfactsheet.php?id=8901> (website visited 16.09.11)

Cabin, R.J., Weller, S.G., Lorence, D.H., Flynn, T.W., Sakai, A.K., Sandquist, D., Hadway L.J., 2000. Effects of long-term ungulate exclusion and recent alien species control on the preservation and restoration of a Hawaiian tropical dry forest. Conserv. Biol. 14, 439-453.

Camp, R.J., Seavy, N.E., Gorresen, P.M., Reynolds, M.H., 2008. A statistical test to show negligible trend: comment. Ecology 89, 1469-1472.

Camp, R.J., Reynolds, M.H., Woodworth, B.L., Gorresen, P.M., Pratt, T.K., 2009 Monitoring Hawaiian forest birds. In: Pratt, T.K., Atkinson, C.T., Banko, P.C. Jacobi, J.D., Woodworth, B.L. (Eds.), Conservation Biology of Hawaiian Forest Birds: Implications for Island Avifauna. Yale University Press, New Haven, pp. 83-107.

Cao, G., Giambelluca, T.W., Stevens, D.E., Schroeder, T.A., 2007. Inversion variability in the Hawaiian trade wind regime. J. Clim. 20, 1145-1160.

Caujapé-Castells, J., Tye, A., Crawford, D.J., Santos-Guerra, A., Sakai, A., Beaver, K., Lobin, W., Florens, F.B.V., Moura, M., Jardim, R., Gómes, I., Kueffer, C., 2010. Conservation of oceanic island floras: present and future global challenges. Perspect. Plant Ecol., Evol. Syst. 12, 107-129.

Chu, P.-S., Chen, H., 2005. Interannual and interdecadal rainfall variations in the Hawaiian Islands. J. Clim. 18, 4796-4813.

Chu, P.-S., Chen, Y.R., Schroeder, T.A., 2010. Changes in precipitation extremes in the Hawaiian Islands in a warming climate. J. Clim. 23, 4881-4900.

Clavel, J., Julliard, R., Devictor, V., 2011. Worldwide decline of specialist species: toward a global functional homogenization? Front. Ecol. Environ. 9, 222-228.

D'Antonio, C.M., Vitousek, P.M., 1992. Biological invasions by exotic grasses, the grass/fire cycle, and global change. Annu. Rev. Ecol. Syst. 23, 63-87. 
Foster, J.T., 2009. The history and impact of introduced birds. In: Pratt, T.K. Atkinson, C.T., Banko, P.C., Jacobi, J.D., Woodworth, B.L. (Eds.), Conservation Biology of Hawaiian Forest Birds: Implications for Island Avifauna. Yale University Press, New Haven, pp. 312-330.

Gardiner, D.E., Trujillo, E.E., 2001. Association of Armillaria mellea with mamane decline at $\mathrm{Pu}^{\prime} \mathrm{u}$ La'au. Newsl. Hawaiian Botanical Soc. 40, 33-34.

Giambelluca, T.W., Luke, M.S.A., 2007. Climate change in Hawai'i's mountains Mountain Views 1, 13-18.

Giffin, J.G., 1976. Ecology of the Feral Sheep on Mauna Kea. Unpublished report, Pittman-Robertson Project W-15-5, Study XI, Hawai'i Department of Land and Natural Resources, Honolulu.

Giffin, J. G., 1980. Ecology of the mouflon sheep on Mauna Kea. Unpublished report Pittman-Robertson Project W-17-R, Study R-III, Hawai'i Department of Land and Natural Resources, Honolulu.

Gorresen, P.M., Camp, R.J., Reynolds, M.H., Woodworth, B.L., Pratt, T.K., 2009. Status and trends of native Hawaiian songbirds. In: Pratt, T.K., Atkinson, C.T. Banko, P.C., Jacobi, J.D., Woodworth, B.L. (Eds.), Conservation Biology of Hawaiian Forest Birds: Implications for Island Avifauna. Yale University Press, New Haven, pp. 108-136.

Harris, G., Pimm, S.L., 2008. Range size and extinction risk in forest birds. Conserv. Biol. 22, 163-171.

Hartt, C.E., Neal, M.C., 1940. The plant ecology of Mauna Kea, Hawaii. Ecology 21, 237-266.

Hess, S.C., Banko, P.C., Brenner, G.J., Jacobi, J.D., 1999. Factors related to the recovery of subalpine woodland on Mauna Kea, Hawaii. Biotropica 31, 212-219.

Hess, S.C., Banko, P.C., Reynolds, M.H., Brenner, G.J., Laniawe, L.P., 2001. Seasona changes in food resource abundance and drepanidine densities in subalpine woodland on Mauna Kea, Hawai'i. Stud. Avian Biol. 22, 154-163.

Hess, S.C., Banko, P.C., 2011. Sheep vs. palila on Mauna Kea: after 200 years of damage, can these native birds recover? Wildlife Professional 5, 60-63.

Holmes, S.A., Webster, C.R., Flaspohler, D.J., Froese, R.E., 2009. Death and Taxus: the high cost of palatability for a declining evergreen shrub, Taxus canadensis. Can. J. For. Res. 39, 1366-1374.

Jacobi, J.D., Fancy, S.G., Giffin, J.G., Scott, J.M., 1996. Long-term population variability in the palila, an endangered Hawaiian honeycreeper. Pac. Sci. 50, 363-370.

Juvik, J.O., Juvik, S.P., 1984. Mauna Kea and myth of multiple use: endangered species and mountain management in Hawaii. Mountain Res. Develop. 4, 191-202.

Juvik, J.O., Nullet, D., Banko, P., Hughes, K., 1993. Forest climatology near the tree line in Hawai'i. Agric. For. Meteorol. 66, 159-172.

Juvik, J.O., Rodomsky, B.T., Price, J.P., Hansen, E.W., Kueffer, C., 2011. The upper limits of vegetation on Mauna Loa, Hawaii: a 50th-anniversary reassessment. Ecology 92, 518-525

Leonard Jr., D.L., Banko, P.C., Brinck, K.W., Farmer, C., Camp, R.J., 2008. Recent surveys indicate rapid decline of palila, population. 'Elepaio 68, 27-30.

Lindsey, G.D., Fancy, S.G., Reynolds, M.H., Pratt, T.K., Wilson, K.A., Banko, P.C., Jacobi, J.D., 1995. Population structure and survival of palila. Condor 97, 528-535.

Lindsey, G.D., Pratt, T.K., Reynolds, M.H., Jacobi, J.D., 1997. Response of six species of Hawaiian forest birds to a 1991-1992 El Nino drought. Wilson Bull. 109, 339343.

Lohse, K.A., Nullet, D., Vitousek, P.M., 1995. Effects of extreme drought on vegetation of a lava flow on Mauna Loa, Hawai'i. Pac. Sci. 49, 212-220.

Loope, L.L., Hamann, O., Stone, C.P., 1988. Comparative conservation biology of oceanic archipelagoes: Hawaii and the Galápagos. Bioscience 38, 272-282.

Loope, L.L., Giambelluca, T.W., 1998. Vulnerability of island tropical montane cloud forests to climate change, with special reference to East Maui, Hawaii. Climatic Change $39,503-517$.
Martin, J.-L., Stockton, S.A., Allombert, S., Gaston, A.J., 2010. Top-down and bottomup consequences of unchecked ungulate browsing on plant and animal diversity in temperate forests: lessons from a deer introduction. Biol. Invasions $12,353-371$.

Niinemets, Ü., 2010. Responses of forest trees to single and multiple environmental stresses from seedlings to mature plants: past stress history, stress interactions, tolerance and acclimation. For. Ecol. Manage. 260, 1623-1639.

Pratt, L.W., Jacobi, J.D., 2009. Loss, degradation, and persistence of habitats. In: Pratt, T.K., Atkinson, C.T., Banko, P.C., Jacobi, J.D., Woodworth, B.L. (Eds.), Conservation Biology of Hawaiian Forest Birds: Implications for Island Avifauna. Yale University Press, New Haven, pp. 137-158.

Pratt, T.K., Banko, P.C., Fancy, S.G., Jacobi, J.D., Lindsey, G.D., 1997. Status and management of the palila, an endangered Hawaiian honeycreeper, 1987-1996. Pac. Conserv. Biol. 3, 330-340.

Pratt, T.K., Atkinson, C.T., Banko, P.C., Jacobi, J.D., Woodworth, B.L., Mehrhoff, L.A., 2009. Can Hawaiian forest birds be saved? In: Pratt, T.K., Atkinson, C.T., Banko, P.C., Jacobi, J.D., Woodworth, B.L. (Eds.), Conservation Biology of Hawaiian Forest Birds: Implications for Island Avifauna. Yale University Press, New Haven, pp. 552-580.

Scott, J.M., Mountainspring, S., van Riper III, C., Kepler, C.B., Jacobi, J.D., Burr, T.A., Giffin, J.G., 1984. Annual variation in the distribution, abundance, and habitat response of the palila (Loxioides bailleui). Auk 101, 647-664.

Scott, J.M., Mountainspring, S., Ramsey, F.L., Kepler, C.B., 1986. Forest bird communities of the Hawaiian Islands: their dynamics, ecology, and conservation. Stud. Avian Biol. 9, 1-431.

Scowcroft, P.G., 1983. Tree cover changes in māmane (Sophora chrysophylla) forests grazed by sheep and cattle. Pac. Sci. 37, 109-119.

Scowcroft, P.G., Giffin, J.G., 1983. Feral herbivores suppress the regeneration of mamane and other browse species on Mauna Kea, Hawaii. J. Range Manag. 36, 638-645.

Scowcroft, P.G., Sakai, H.F., 1983. Impact of feral herbivores on mamane forests of Mauna Kea, Hawaii: Bark stripping and diameter class structure. J. Range Manag. 36, 495-498.

Scowcroft, P.G., Conrad, C.E., 1988. Restoring critical habitat for Hawaii's endangered palila by reducing ungulate populations. Trans. Western Sect. Wildlife Soc. 24, 72-79.

Sekercioğlu, C.H., Schneider, S.H., Fay, J.P., Loarie, S.R., 2008. Climate change, elevational range shifts, and bird extinctions. Conserv. Biol. 22, 140-150.

Şekercioğlu, C.H., Primack, R.B., Wormworth, J., 2012. The effects of climate change on tropical birds. Biol. Conserv. 148, 1-18.

Snetsinger, T.J., 1995. Observations of a Hawai'i creeper in mamane, forest. 'Elepaio $55,55-56$

Spear, D., Chown, S.L., 2009. Non-indigenous ungulates as a threat to biodiversity. J. Zool. 279, 1-17.

Thaxton, J.M., Jacobi, J.D., 2009. Assessment of Fuels, Potential Fire Behavior, and Management Options in Subalpine Vegetation on Mauna Kea Volcano, Hawai'i. Technical Report HCSU-013, Hawai'i Cooperative Studies Unit, Pacific Aquaculture and Coastal Resources Center, University of Hawai'i at Hilo.

U.S. Fish and Wildlife Service, 2006. Revised Recovery Plan for Hawaiian Forest Birds. Region 1, Portland, Oregon.

van Riper III, C., Scott, J.M., Woodside, D.M., 1978. Distribution and abundance patterns of the palila on Mauna Kea, Hawaii. Auk 95, 518-527.

Warner, R.E., 1960. A forest dies on Mauna Kea. Pac. Discovery 13, 6-14.

Williams, A.C. 1994. Effects of Non-Native Grasses on a dry Subalpine Forest Native to Hawaii And A Discussion of Effects of Canopy on Understory Productivity. M.S. Thesis, University of California, Berkeley. 